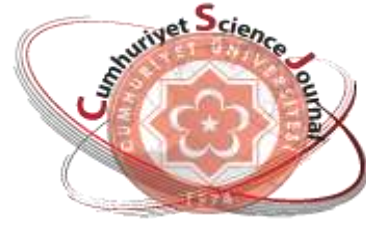

e-ISSN: $2587-246 X$

ISSN: $2587-2680$

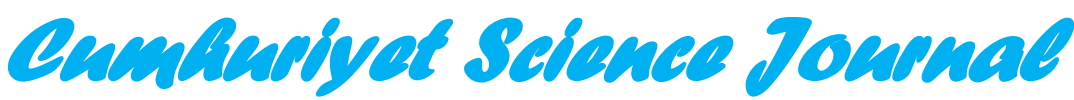

$\cos 7$

Cumhuriyet Sci. J., Vol.38-4, Supplement (2017) 60-67

\title{
A Preliminary Study of Using Some Nest Characteristics as Indicators for the Size of Green Turtle (Chelonia mydas) Hatchlings
}

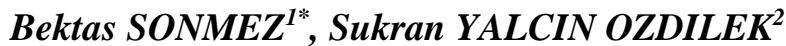

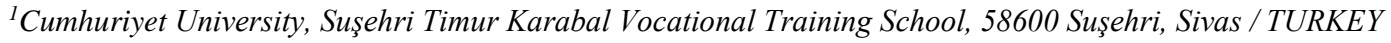 \\ ${ }^{2}$ Canakkale Onsekiz, Mart University Faculty of Science and Arts, Department of Biology, Ecology Division, Terzioglu \\ Campus 17100 Çanakkale / TURKEY
}

Received: 14.02.2017; Accepted: 30.10.2017

http://dx.doi.org/10.17776/csj.363298

\begin{abstract}
Body size can increase or decrease the chances of survival of sea turtle hatchlings. Given the importance of body size for hatchling survival, it would be useful method for conservationists to be able to estimate, using indicators, hatchling size quickly without having to disturb hatchlings. Some nest characteristics such as clutch size, distance of the nest from the sea, incubation period and nest depth were tested for correlations with hatchling size in a population of Chelonia mydas in Turkey to determine if they can be indicators for hatchling size. Our results showed that none of these nest characteristics were suitable. However; incubation period showed weakly correlated with straight carapace size. When the best fitting linear model of the effect of principal components (PCs), derived from collinear nest characteristics, on hatchling size was constructed, the model only explained $19.75 \%$ of the variance in hatchling size. PC2 had a significant effect on straight carapace length (SCL) and the interaction between PC1 and PC2 had significant effects on SCL and curved carapace length (CCL) in the univariate analysis. F-test results that suggested the models had not significant predictive capabilities. Perhaps there may be other factors that are more suitable as indicators, or that hatchling size is influenced by a complex interplay among several factors, such that it is not possible to identify a few key factors to be used as indicators.
\end{abstract}

Keywords: Chelonia mydas, Hatchling Size, Hatchling Morphometrics, Nest Characteristics, Samandağ

\section{Yeşil Deniz Kaplumbağası (Chelonia mydas) Yavrularının Büyüklüğü için Indikatör Olarak Bazı Yuva Özelliklerinin Kullanılmasıyla İlgili Bir Ön Çalışma}

Özet: Vücut büyüklüğü, deniz kaplumbağası yavrularının hayatta kalma şansını artırabilir veya azaltabilir. Deniz kaplumbağası yavrusunun hayatta kalabilirliği için vücut büyüklüğünün önemi göz önüne alındığında, indikatör kullanılarak, yavru büyüklüğünün tahmin edilmesi koruma uzmanları için yararlı bir yöntem olacaktır. Türkiye'de Chelonia mydas popülasyonunda, yavru büyüklüğü için indikatör olup olmayacaklarını belirlemek amacıyla, yumurta sayısı, yuvanın denize olan uzaklığı, kuluçka süresi ve yuva derinliği gibi bazı yuva özellikleri yavru büyüklüğü ile korelasyona tabi tutuldu. Bulgularımız, bu yuva özelliklerinden hiçbirinin yavru büyüklüğünü tahmin etmek için uygun olmadığını göstermiştir. Ancak, kuluçka süresi, yavrunun düz karapas boyu ile zayıf bir korelasyon göstermiştir. Kollinear yuva özelliklerinden türetilen ana bileşenlerin (AB), yavru büyüklüğüne en iyi uyan doğrusal modeli oluşturulduğu zaman, model yavru büyüklüğündeki varyansın sadece \% 19.75'ini açıkladı. AB2'nin doğru karapas boyu (DKB) üzerinde anlamlı bir etkisi vardı ve AB1 ile AB2

\footnotetext{
*Corresponding author.Email address: bsonmez@cumhuriyet.edu.tr, bektass@gmail.com http://dergipark.gov.tr/csj $\quad$ C2016 Faculty of Science, Cumhuriyet University
} 
arasındaki etkileşim, tek değişkenli analizde DKB ve eğri karapas boyu (EKB) üzerinde belirgin etkilere sahipti. F-test sonuçları, modellerin belirgin öngörü yeteneğinin olmadığını önermektedir. Belki de, araştırılmayan diğer faktörler indikatör olarak daha uygun olabilir veya yavru büyüklüğü, indikatör olarak kullanılabilir ancak tespiti yapılamayan bir kaç temel faktör gibi çeşitli faktörler arasındaki karmaşık bir etkileşimden etkileniyordur.

Anahtar Kelimeler: Chelonia mydas, Yavru Büyüklüğü, Yavru Morfolojisi, Yuva özellikleri, Samandağ

\section{INTRODUCTION}

Body size and shape have important physiological, evolutionary and ecological implications (such as fitness, survival and swimming) for sea turtles. The morphology of hatchlings can increase or decrease their chances of survival and can be affected by both genetic and maternal characteristics, as well as environmental factors $[1,2]$.

For example, it has been suggested that hatchling size has important fitness consequences $[3,4,5]$, while hatchling mass may not differ much, the ratio in which mass is distributed between body tissues and the attached remnant yolk of hatchlings may vary among different nests. In an environment where food is abundant, hatchlings with larger bodies and smaller yolk reserves have a higher fitness advantage since they can process larger prey and are less likely to be eaten by slower and gapelimited predators due to their faster swimming ability and larger size, i.e. the 'bigger is better' hypothesis [3]. Conversely, in a food-scarce environment, it is more advantageous for hatchlings to have smaller bodies and larger yolk reserves as they can survive for a longer period without feeding.

Body size estimation of hatchlings can be done via indicators without disturbing them. For the purposes of this paper, indicators are defined as quantifiable descriptive 'measurements' used to reflect attributes of the 'indicanda' (i.e. the phenomena of interest being indicated) [6]. These measurements must be qualitatively and quantitatively correlated with parameter values of the indicanda, preferably in a direct causal relationship [6]. Good indicators should obviously describe the indicanda accurately, but they should also be user-friendly: simple to measure, manage and analyse and do not demand too many resources and time [7]. Depending on the user for whom the indicators are designed, some accuracy may have to be sacrificed for ease of application of the indicators.

In this study, we tested the feasibility of using various easily measured nest characteristics, such as clutch size (CS), distance of the nest from the sea (DFS), incubation period (IP) and nest depth (ND) as indicators for hatchling size according to the correlations between them and hatchling size in a sample population of Chelonia mydas in Turkey. Some of these characteristics such as ND, DFS and IP have been shown to correlate with nest temperature and/or moisture [8-11], which affect hatchling size $[5,12]$.

\section{MATERIALS AND METHODS}

This study was conducted in the nesting season of

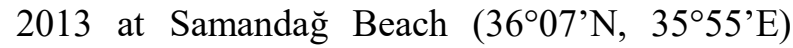
which is on the south-eastern coast of Turkey (Figure 1). 


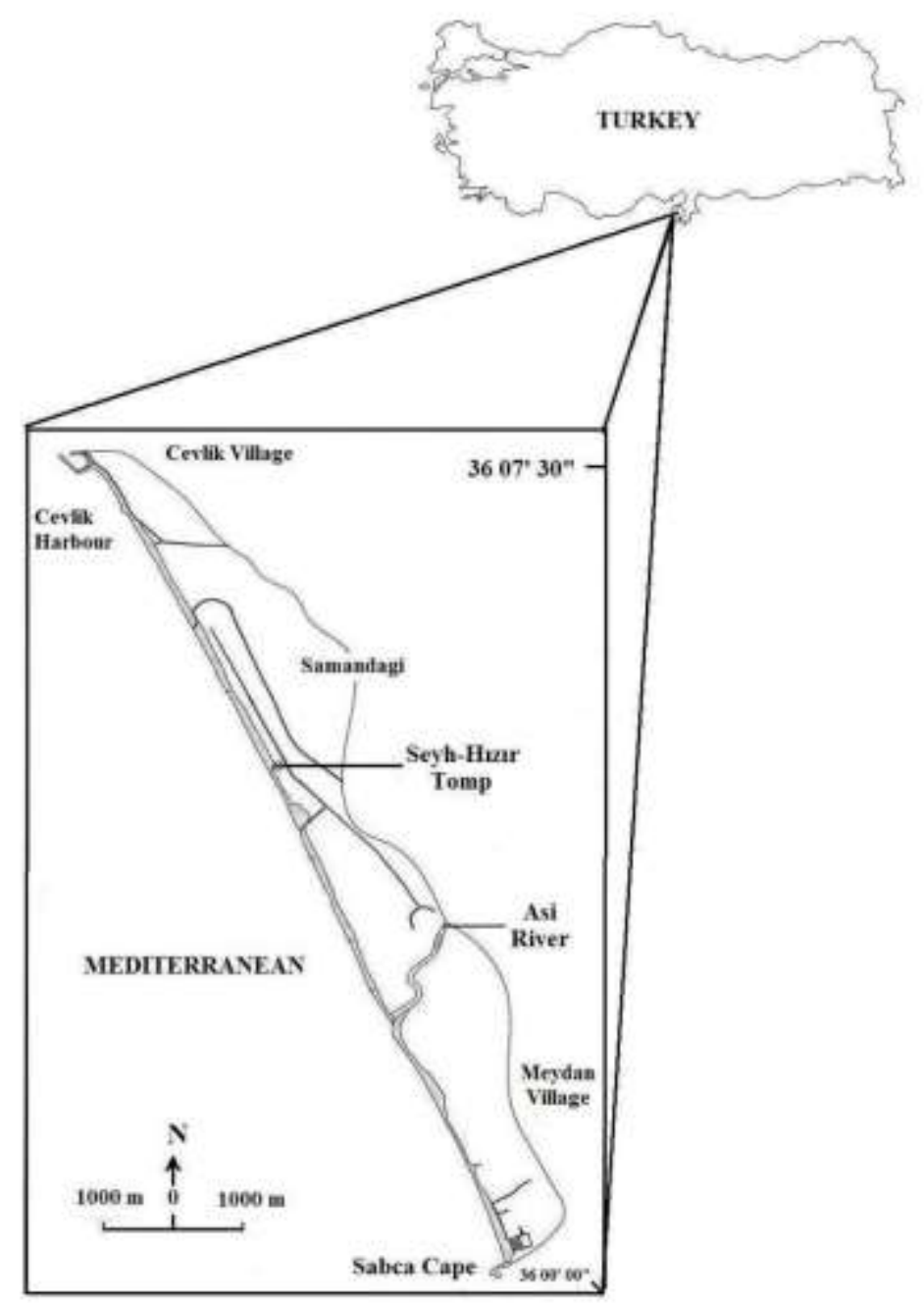

Figure 1. The map of study area.

Based on the modal inter-nesting interval of female C. mydas [13], all nests were selected within $10-$ 13 days to make sure that all nests belonged to different females, and totally 40 nests were sampled. After 40 days of incubation, the area above each nest was enclosed by a circular low wire fence with a diameter of two metres. The fences were closed at night, preventing hatchlings from making their way to the sea, and opened again in the morning so that hatchlings emerging during the heat of the day were able to move freely. Nests were checked every night and throughout the night. Upon emergence of hatchlings, they were measured for their size in four dimensions, straight carapace length (SCL), straight carapace width (SCW), curved carapace length (CCL) and curved carapace width (CCW) (Figure 2). Straight measurements were taken using manual callipers and curved measurements were taken using a plastic tape measure. In each nest, 17 to 20 hatchlings were measured and subsequently released. A total of 785 hatchlings were measured. 


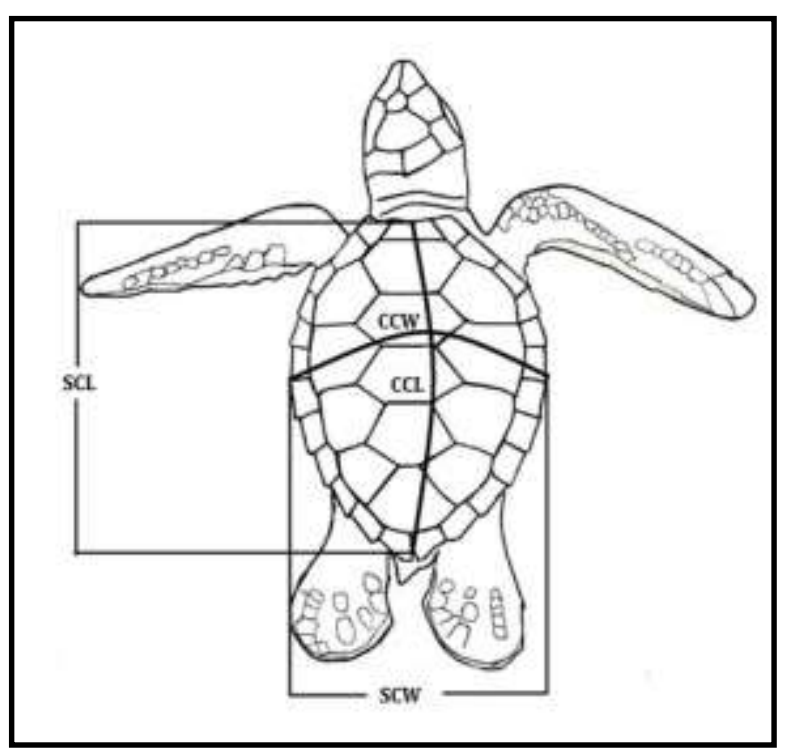

Figure 2. Measurements of C. mydas hatchling size dimensions (SCL: Straight Carapace Length, SCW: Straight Carapace Width, CCL:Curved Carapace Length, CCW:Curved Carapace Width).

DFS of each nest was measured with a flexible tape measure when the nest was found. IP of each nest was defined as the number of days between the night when the nest was laid and the night when the first group of hatchlings emerged. Eight to ten days after the last observed emergence of hatchlings, nests were excavated. During the excavation, CS of each nest was determined by counting the number of unhatched eggs and hatched eggs. Concurrently, ND of each nest was measured with a flexible tape measure as a straight vertical distance from the sand surface to the deepest point of the nest.

The relationships between mean hatchling size (SCL, SCW, CCL and CCW) of each nest and nest characteristics (CS, DFS, IP and ND) were analysed with the Pearson's correlation coefficient. This was also used to check for collinearity between potential indicators (i.e. nest characteristics). Collinear predictors were reduced, using Principal Components Analysis (PCA), to orthogonal variables, which were used in subsequent model building. To determine if there were any interaction effects between the potential indicators, and to detect if there were overall effects on the mean hatchling size that may not be apparent by examining an individual mean dimension alone, a multivariate analysis was carried out using the mvabund package for R [14], where a single linear model with a Gaussian error distribution is fitted to all four mean hatchling size concurrently after 1000 Bootstrap iterations. To find out which of the mean hatchling size expressed significant effects, mvabund was also used to compute univariate statistics describing the significance of the principal components for each individual mean dimension. The univariate statistics were adjusted to control for family-wise error rates [14]. To ensure the reliability of the model, the normality of residuals, homoscedasticity and lack of high leverage points were checked.

Statistical tests were performed using the $\mathrm{R}$ software (Version 2.15.1, The R Foundation for Statistical Computing).

\section{RESULTS}

A total of 2427 green turtle emergences was recorded, $1172(48.3 \%)$ of which resulted in nests during the 2013 nesting season. The mean distance from the sea of green turtle nests was 30.8 meters. The mean nest depth of green turtle nests was 75.8 $\mathrm{cm}$. The mean incubation time was calculated as 52.5 days for green turtles. The mean clutch size of green turtles was 106 eggs. The descriptive statistics of hatchling size (mean values for each nest) and nest characteristics are given in Table 1 .

Table 1. Descriptive statistics of hatchling size and nest characteristics. (SCL: Straight Carapace Length, SCW: Straight Carapace Width, CCL: Curved Carapace Length, CCW: Curved Carapace Width, CS: Clutch Size, DFS: Distance of the Nest From the Sea, IP: Incubation Period, ND Nest Depth) $(n=40)$.

\begin{tabular}{lllll}
\hline Variable & Mean & SE & Min. & Max. \\
\hline SCL $(\mathbf{c m})$ & 4.52 & 0.02 & 4.12 & 4.74 \\
SCW $(\mathbf{c m})$ & 3.41 & 0.02 & 3.04 & 3.61 \\
CCL $(\mathbf{c m})$ & 4.98 & 0.02 & 4.63 & 5.27 \\
CCW $(\mathbf{c m})$ & 4.32 & 0.01 & 4.06 & 4.55 \\
CS & 96.7 & 3.21 & 39 & 135 \\
DFS (m) & 39.8 & 2.08 & 17 & 74 \\
IP $($ days) & 49.3 & 0.34 & 47 & 54 \\
ND $(\mathbf{c m})$ & 73.9 & 1.06 & 62 & 89 \\
\hline
\end{tabular}


All mean hatchling size were correlated with each other (Table 2). DFS was negatively correlated with CS and IP. None of the nest characteristics correlated with the mean hatchling size, except IP which mildly correlated with SCL and SCW (Table 2). CS, DFS and IP showed collinearity (Table 2).

Table 2. Pearson's correlation matrix between straight carapace length (SCL), straight carapace width (SCW), curved carapace length (CCL), curved carapace width (CCW), clutch size (CS), distance of the nest from the sea (DFS), incubation period (IP) and nest depth (ND). (*, $P<0.05 ; * *, P<0.01 ; * * *, P<0.001 ; \mathrm{n}=40)$.

\begin{tabular}{|c|c|c|c|c|c|c|c|}
\hline & SCL & SCW & CCL & CCW & $\mathrm{CS}$ & DFS & IP \\
\hline SCW & $0.79 * * *$ & & & & & & \\
\hline CCL & $0.92^{* * *}$ & $0.66 * * *$ & & & & & \\
\hline $\mathrm{CCW}$ & $0.76^{* * *}$ & $0.79 * * *$ & $0.78^{* * *}$ & & & & \\
\hline CS & -0.02 & -0.07 & -0.04 & 0.00 & & & \\
\hline DFS & -0.28 & -0.21 & -0.18 & -0.23 & $-0.48^{* *}$ & & \\
\hline IP & $0.35^{*}$ & $0.32 *$ & 0.20 & 0.27 & 0.15 & $-0.39 *$ & \\
\hline ND & 0.01 & -0.12 & 0.11 & -0.01 & 0.19 & 0.06 & -0.07 \\
\hline
\end{tabular}

The nest characteristics were reduced to two orthogonal variables after PCA (Figure 3). PC1 explained $43 \%$ of hatchling size variation and can be understood as comprising mainly of DFS negatively associated with CS and IP. PC2 explained $28 \%$ of hatchling size variation and can be understood as comprising mainly of ND.

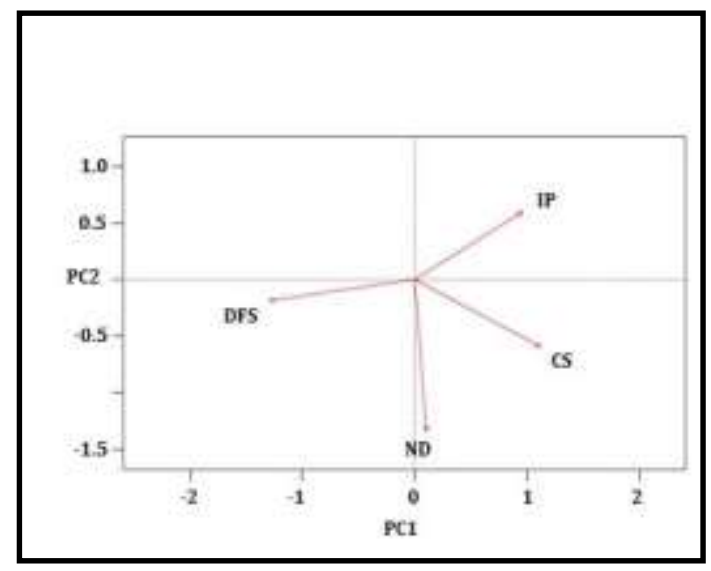

Figure 3. Principal components analysis unrotated ordination plot of nest characteristics. (CS: Clutch Size, DFS: Distance of the Nest from the Sea, IP: Incubation Period, ND Nest Depth).
There is no strong evidence from the best-fitting linear model to suggest that PCs derived from nest characteristics have any correlations with mean hatchling size (Table 3). In the multivariate analysis, although the interaction between $\mathrm{PC} 1$ and PC2 had a significant effect, the multivariate linear model only explained $19.75 \%$ of the variance in mean hatchling size (Lawley-Hotelling trace $=$ $6.959, p=0.026$, Hooper's $R^{2}=19.75 \%$ ). Also, in the univariate analysis, although it seemed that PC2 had a significant effect on SCL and the interaction between PC1 and PC2 had significant effects on SCL and CCL, none of the univariate linear model shad overall $F$-test results that suggested the models had significant predictive capabilities (SCL: $F=3.568, p=0.055$, SCW: $F=2.679, p=$ 0.088, CCL: $F=3.561, p=0.055$, CCW: $F=2.112$, $p=0.097$, Table 3). Multivariate analysis describes the significance of the PCs for all four mean hatchling size concurrently while univariate analysis describes the significance of the PCs for each individual mean dimension. Reducing the predictor parameters in the univariate analysis did not improve the results but instead, resulted in worse performing models with overall F-test results having higher $p$ values (results not shown). 
Table 3. Results of the best fitting multivariate linear model of the effect of principal components (PC1 and PC2) on mean hatchling size of each nest. ':' denotes interaction. $(n=40)$.

\begin{tabular}{|c|c|c|c|c|c|c|c|c|c|c|}
\hline \multirow{3}{*}{ Variables } & \multicolumn{4}{|c|}{ Multivariate Analysis } & \multicolumn{6}{|c|}{ Univariate Analysis } \\
\hline & \multirow[b]{2}{*}{$F$} & \multirow[b]{2}{*}{$p$} & \multicolumn{2}{|c|}{ SCL } & \multicolumn{2}{|c|}{ SCW } & \multicolumn{2}{|c|}{ CCL } & \multicolumn{2}{|c|}{$\mathrm{CCW}$} \\
\hline & & & $F$ & $p$ & $F$ & $p$ & $F$ & $p$ & $F$ & $p$ \\
\hline Intercept & $1.27 \times 10^{5}$ & $<0.001$ & 51396.77 & $<0.001$ & 31534.91 & $<0.001$ & 63395.91 & $<0.001$ & 77051.50 & $<0.001$ \\
\hline PC1 & 8.02 & 0.051 & 5.256 & 0.068 & 2.751 & 0.159 & 2.861 & 0.159 & 3.243 & 0.153 \\
\hline $\mathrm{PC} 2$ & 5.09 & 0.132 & 2.266 & 0.022 & 4.166 & 0.101 & 0.503 & 0.462 & 1.372 & 0.334 \\
\hline $\mathrm{PC} 1: \mathrm{PC} 2$ & 12.72 & 0.016 & 6.441 & 0.039 & 3.423 & 0.095 & 9.576 & 0.012 & 3.641 & 0.095 \\
\hline
\end{tabular}

\section{DISCUSSION}

Our results show that none of the nest characteristics we tested were suitable as indicators of hatchling size. This mirrors observations by Horne et al. (2014) [15] who found that hatchling mass for loggerhead sea turtles on Alagadi beach in northern Cyprus was not significantly influenced by CS and ND. While one nest characteristic, i.e. IP, correlated significantly with two mean hatchling size, that is SCL and SCW, the small correlation coefficients indicate that much uncertainty still exists when using IP as a proxy for hatchling size. Although results of the linear model suggested that an interaction between all four nest characteristics was correlated with mean hatchling size, the small $\mathrm{R}^{2}$ value of the linear model, similar to the case of small correlation coefficients, indicate much uncertainty when using PC1:PC2 as a proxy for hatchling size. Another disadvantage of $\mathrm{PC} 1: \mathrm{PC} 2$ is that it is not a parameter that is intuitively easy to understand.

We speculate the following reasons to explain our failure to find suitable indicators in this study:

1. There may perhaps be other factors (may or may not be related to nest characteristics, e.g. sand grain size) that correlate better with hatchling size. For example, hatchling size is known to be mainly affected by nest temperature and water availability [5, 12]. However, there exists temporal variation in nest temperature $[16,17]$ and water availability [18, 19], which necessitates multiple sampling over a period of time. Therefore, taking snapshot measurements at one moment during the nesting season may be insufficient. Instead, short of measuring hatchlings directly, continuous monitoring of how indicator measurements change during a nesting season may be necessary for more accurate estimation of hatchling size. Such an approach has been used to investigate how temperature variation influences hatchling mass [15].

2. Considering that hatchling morphology can be influenced by both genetic and environmental factors $[1,2]$, it is not unreasonable to infer that only some hatchling size have variations that are more environmentally influenced, thus rendering themselves to be more easily reflected using nest characteristics. It was shown that SCL, but not SCW, of loggerhead sea turtles varied with differing moisture levels of the incubating sand [20]. This was somewhat inconclusively hinted at from our results of the univariate analysis of our bestfitting linear model, where predictor parameters had significant effects on SCL and CCL only. Perhaps more focus should be given to carapace length when identifying environmental indicators of hatchling size. On the other hand, maternal characteristics reflecting genetic influences (such as female size) can be another source of indicators worth investigating.

Hatchling size in C. mydas is influenced by a complex interplay among several factors; therefore it is not possible to identify a few factors that play a key role in influencing hatchling size, to be used as indicators. More research should be conducted 
to address the above-mentioned speculations. Ultimately, it is hoped that a comprehensive management toolkit for conservationists can be developed for easy application in the field.

\section{Acknowledgments.}

The authors thanks to Yusuf GENÇ, Onurcan KESKIN and Anıl MANSUROĞLU and the student volunteers, whose names we could not mention here, for their support. The beach survey was realized by a cooperative protocol between the Ministry of Forestry and Waters in Turkey and the Society for Environmental Protection and Tourism of Samandağ. Special thanks Ter Yang GOH for comments and suggestions and statistical tests.

\section{REFERENCES}

[1]. Glen F., Broderick A.C., Godley B.J., Hays G.C. Incubation environment affects phenotype of naturally incubated green turtle hatchlings. Journal of the Marine Biological Association of the United Kingdom, 2003; 83: 1183-1186.

[2]. Burgess E.A., Booth D.T., Lanyon J.M. Swimming performance of hatchling green turtles is affected by incubation temperature. Coral Reefs, 2006; 25: 341-349. doi: 10.1007/s00338-006-0116-7

[3]. Booth D.T., Burgess E., McCosker J., Lanyon J.M. The influence of incubation temperature on post-hatching fitness characteristics of turtles. International Congress Series, 2004; 1275: 226-233. doi: 10.1016/j.ics.2004.08.057

[4]. Booth D.T. Influence of incubation temperature on hatchling phenotype in reptiles. Physiological and Biochemical Zoology, 2006; 79: 274-281. doi: $10.1086 / 499988$

[5]. Sönmez B., Turan C., Yalçın-Özdilek Ş. The effect of relocation on the morphology of green turtle, Chelonia mydas (Linnaeus, 1758), hatchlings on Samandağ beach, Turkey. Zoology in the Middle East, 2011; 52: 29-38. doi: 10.1080/09397140.2011.10638476
[6]. Heink U. and Kowarik I. What are indicators? On the definition of indicators in ecology and environmental planning. Ecological Indicators, 2010; 10: 584-593. doi: 10.1016/j.ecolind.2009.09.009

[7]. Niemeijer D. and de Groot R.S. A conceptual framework for selecting environmental indicator sets. Ecological Indicators, 2008; 8: 14-25. doi: 10.1016/j.ecolind.2006.11.012

[8]. Packard G.C. and Packard M.J. The physiological ecology of reptilian eggs and embryos. In: Gans, C. and Huey, R.B (eds), Biology of the Reptilia, Volume 16, (pp 524 - 605). Alan R. Liss. Press, 1988.

[9]. Candan O. and Kolankaya D. Sex ratio of green turtle (Chelonia mydas) hatchlings at Sugözü, Turkey: higher accuracy with pivotal incubation duration. Chelonian Conserv. Biol., 15 (2016), pp. 102-108.

[10]. Kılıç Ç and Candan O. Hatchling sex ratio, body weight and nest parameters for Chelonia mydas nesting on Sugözü beaches (Turkey) Anim. Biodivers. Conserv., 37 (2014), pp. 177-182

[11]. Özdemir, B. \& Türkozan, O. Hatching success of original and hatchery nests of the green turtle, Chelonia mydas, in Northern Cyprus. Turkish Journal of Zoology, 2006; 30: 377-381.

[12]. Booth D.T., Feeney R., Shibata Y. Nest and maternal origin can influence morphology and locomotor performance of hatchling green turtles (Chelonia mydas) incubated in field nests. Marine Biology, 2013; 160: 127137. doi: 10.1007/s00227-012-2070-y

[13]. Broderick A.C., Glen F., Godley B.J., Hays G.C. Estimating the number green and loggerhead turtles nesting annually in the Mediterranean. Oryx, 2002; 36: 227-235. doi: $10.1017 /$ S0030605302000431

[14]. Wang Y., Naumann U., Wright S.T., Warton D.I. Mvabund - an R Package for modelbased analysis of multivariate abundance data. Methods in Ecology and Evolution, 2012; 3: 471-474. doi: 10.1111/j.2041210X.2012.00190.x 
[15]. Horne C.R., Fuller W.J., Godley B.J., Rhodes K.A., Snape R., Stokes K.L., Broderick A.C. The effect of thermal variance on the phenotype of marine turtle offspring. Physiological and Biochemical Zoology, 2014; 87: 796-804. doi: 10.1086/678238

[16]. Godley, B.J., Broderick, A.C., Downie, J.R., Glen, F., Houghton, J.D., Kirkwood, I., Reece, S., Hays, G.C. Thermal conditions in nests of loggerhead turtles: Further evidence suggesting female skewed sex ratios of hatchling production in the Mediterranean. Journal of Experimental Marine Biology and Ecology, 2001; 263: 45-63. doi: 10.1016/S0022-0981(01)00269-6

[17]. Mickelson L.E. \& Downie J.R. Influence of incubation temperature on morphology and locomotion performance of leatherback (Dermochelys coriacea) hatchlings.
Canadian Journal of Zoology, 2010; 88: 359368. doi: 10.1139/Z10-007

[18]. Packard G.C., Paukstis G.L., Boardman T.J., Gutzke W.H.N. Daily and seasonal variation in hydric conditions and temperature inside nests of common snapping turtles (Chelydra serpentina).

Canadian Journal of Zoology, 1985; 63: 2422-2429. doi: 10.1139/z85-358

[19]. Delmas V., Bonnet X., Girondot M., PrévotJulliard A.C. Varying hydric conditions during incubation influence egg water exchange and hatchling phenotype in the red-eared slider turtle. Physiological and Biochemical Zoology, 2008; 81:(3) 345-55. doi: $10.1086 / 529459$

[20]. Mcgehee M.A. Effects of moisture on eggs and hatchlings of loggerhead sea turtles (Caretta caretta). Herpetologica, 1990; 46: 251-258. 